\title{
CLINICAL ANALYSIS OF BLOOD TRACES OF RATS AFTER SUBCUTANEOUS IMPLANTATION OF Nd-Fe-B MAGNETS WITH PROTECTIVE PVD ZrN COATINGS
}

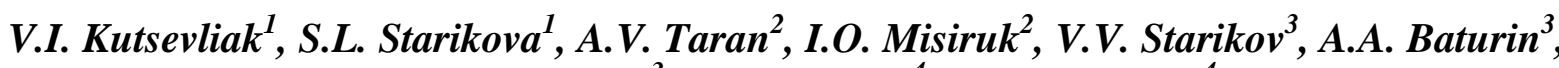 \\ N.V. Konotopska ${ }^{3}$, L.M. Dushyk ${ }^{4}$, N.V. Cherkova ${ }^{4}$ \\ ${ }^{1}$ Kharkiv Medical Academy of Postgraduate Education, Kharkiv, Ukraine; \\ ${ }^{2}$ Institute of Plasma Physics, National Science Center "Kharkov Institute of Physics and \\ Technology", Kharkiv, Ukraine; \\ ${ }^{3}$ National Technical University "Kharkiv Polytechnic Institute", Kharkiv, Ukraine; \\ ${ }^{4}$ V.N. Karazin Kharkiv National University, Kharkiv, Ukraine

\section{E-mail:avtaran@ukr.net}

It is possible to increase the effectiveness of treatment of various anomalies of occlusion with the help of orthodontic appliances, including permanent magnets as components. But a significant disadvantage of magnetic materials is low corrosion resistance, which can be prevented by applying to the magnets various PVD protective coatings leading to passivation of the surface of the magnetic material. The effect of Nd-Fe-B magnets with and without protective $\mathrm{ZrN}$ coating after subcutaneous implantation in rats on the results of laboratory blood tests has been evaluated.

PACS: 52.77.-j; 81.20.-n

\section{INTRODUCTION}

The use of orthodontic appliances with magnets for the treatment of pathologies of occlusion has a number of advantages [1, 2]. In this case, it is significantly easier to brush teeth by simplifying the design of the device, which reduces the number of additional elements that create retention points, where food residues can accumulate. In addition, in devices with magnets there is a transfer of forces without friction, and it is possible to calculate the magnitude of the force with high accuracy [3]. The most promising magnetic materials for orthodontics are $\mathrm{Sm}-\mathrm{Co}$ and $\mathrm{Nd}-\mathrm{Fe}-\mathrm{B}$ alloys, which show high forces between magnetic interactions, are quite sufficient for effective movement of teeth in the case of small size (volume) of the magnets themselves [4]. It should also be noted that modern magnetic materials show high stability of physical properties. A significant disadvantage of magnetic materials is low corrosion resistance, which leads to the destruction of the magnet due to electrochemical corrosion in the aggressive environment of the oral cavity [5].

The situation that has arisen can be corrected by applying different types of protective coatings to the magnets, which lead to passivation of the surface of the magnetic material. Such coatings can be oxide or nitride films based on PVD coatings [6], as well as polymeric materials used in dentistry [7]. However, at present in the scientific literature there is a lack of information about the methods of passivation of the surface of magnets used in orthodontic appliances, as well as about the characteristics of the effectiveness of protective coatings, which makes our research relevant.

The aim of the research was to evaluate the effect of magnets with and without protective $\mathrm{ZrN}$ coating on the experimental rats after subcutaneous implantation based on the results of laboratory blood tests.

\section{EXPERIMENTAL}

The research was conducted on the basis of the experimental-biological clinic of "Sytenko Institute of Spine and Joints Pathology of NAS of Ukraine" and Kharkiv Medical Academy of Postgraduate Education of the Ministry of Health of Ukraine according to the agreement on scientific and practical cooperation. All experiments on animals were performed in compliance with the requirements of the European Convention for the Protection of Vertebrate Animals Used for Experimental and Other Scientific Purposes (Strasbourg, 1986) and the Law of Ukraine № 3447-IV of 21.02.2006 "On the Protection of Animals from Cruelty". The $\mathrm{ZrN}$ protective coatings were applied on the surface of $\mathrm{Nd}-\mathrm{Fe}-\mathrm{B}$ magnets at the Institute of Plasma Physics NSC KIPT by using Bulat-type facility [8-11].

The studies were performed on 49 male rats, animal age $3 . . .3 .5$ months, body weight $180 \ldots 250 \mathrm{~g}$, and 7 rats for 3 study periods. The first experimental group - rats implanted with $\mathrm{Nd}-\mathrm{Fe}-\mathrm{B}$ magnet with a protective $\mathrm{ZrN}$ coating; the second - rats implanted with $\mathrm{Nd}-\mathrm{Fe}-\mathrm{B}$ magnet without a protective coating; third - intact animals. The number of erythrocytes and leukocytes, hemoglobin content and leukogram were determined in the blood of rats on 7, 14, and 45 days [12]. The content of glycoproteins, glucose, total protein, urea, ALT and AST activity, the content of total bilirubin and Fe were determined in the serum of rats according to the methods described in the literature [13]. Statistical analysis of the data was performed using the 
nonparametric Wilcoxon test with calculations of the median (Me) and percentiles (25 and $75 \%$ ) [14].

\section{RESULTS AND DISCUSSION}

In rats implanted with magnets with or without a protective $\mathrm{ZrN}$ coating, hematological parameters did not differ from those of intact animals during 7, 14, and 45 days of implantation (Tables 1,2).

Biochemical markers of rats' blood after subcutaneous implantation of magnets without a protective coating partially changed on both the $7^{\text {th }}$ and $14^{\text {th }}$ day of observation. Indicators of total protein, AST activity and total bilirubin did not change during the experiment. The content of glycoproteins in the blood of rats on the $7^{\text {th }}$ day after implantation was increased by $27.0 \%$, on the $14^{\text {th }}$ day - by $8.7 \%$ for relatively intact animals. The content of glycoproteins on the $14^{\text {th }}$ day was lower by $14.4 \%$ compared with that on the $7^{\text {th }}$ day (Table 3).

Table 1

Dynamics of hematological parameters in rats after subcutaneous implantation of magnets without protective $\mathrm{ZrN}$ coating (Me, 25...75\%)

\begin{tabular}{|c|c|c|c|c|}
\hline \multirow{2}{*}{ Indicators } & \multirow{2}{*}{$\begin{array}{c}\text { Intact } \\
\text { rats, } \\
\mathrm{N}=7 \\
\end{array}$} & \multicolumn{3}{|c|}{ Days after implantation } \\
\hline & & 7 & 14 & 45 \\
\hline \multirow{2}{*}{$\begin{array}{l}\text { Erythrocytes, } \\
\text { T / L }\end{array}$} & 7.00 & 7.30 & 7.30 & 7.20 \\
\hline & $6.85 \ldots 7.20$ & $7.15 \ldots 7.54$ & $6.90 \ldots .7 .55$ & $6.95 \ldots 7.35$ \\
\hline \multirow[b]{2}{*}{$\begin{array}{l}\text { Hemoglobin, } \\
\mathrm{g} / 1\end{array}$} & 144.0 & 143.0 & 145.0 & 143.0 \\
\hline & $141.5 \ldots 146.5$ & $141.5 . . .147 .5$ & $140.5 \ldots . .146 .0$ & $140.5 \ldots .146 .0$ \\
\hline \multirow{2}{*}{$\begin{array}{l}\text { Eoenophilia, } \\
\text { percent }\end{array}$} & 2.0 & 1.0 & 2.0 & 2.0 \\
\hline & $1.0 \ldots 2.0$ & $1.0 \ldots 4.0$ & $1.0 \ldots 2.0$ & $2.0 \ldots 3.0$ \\
\hline $\begin{array}{l}\text { Neutrophils, } \\
\text { percent }\end{array}$ & - & - & - & - \\
\hline Young & 0 & 0 & 0 & 0 \\
\hline \multirow[b]{2}{*}{ Rod shapad } & 1.0 & 1.0 & 2.0 & 1.0 \\
\hline & $1.0 \ldots 2.0$ & $1.0 \ldots 2.0$ & $1.0 \ldots 3.0$ & $1.0 \ldots 2.0$ \\
\hline \multirow[b]{2}{*}{ Segmentedcore } & 21.0 & 21.0 & 21.0 & 23.0 \\
\hline & $20.0 \ldots 23.0$ & $16.0 \ldots .27 .0$ & $19.0 \ldots .22 .0$ & $21.0 \ldots 24.0$ \\
\hline \multirow{2}{*}{$\begin{array}{l}\text { Lymphocytes, } \\
\text { percent }\end{array}$} & 69.0 & 65.0 & 69.0 & 66.0 \\
\hline & $67.0 \ldots 71.0$ & $61.0 \ldots 69.0$ & $67.0 \ldots 71.0$ & $66.0 \ldots 70.0$ \\
\hline & 7 & 9 & 6 & 7 \\
\hline $\begin{array}{l}\text { Monocyt, } \\
\text { percent }\end{array}$ & $6.0 \ldots 8.0$ & $5.0 \ldots 12.0$ & $5.0 \ldots 9.0$ & $6.0 \ldots 8.0$ \\
\hline
\end{tabular}

The blood glucose content of rats on day 7 was increased by $31.5 \%$ however, on day 14 , blood glucose levels were not elevated compared to intact animals. This is apparently due to hyperglycemia due to the body's stress response at the end of the early postoperative period. ALT activity and urea content were increased only on the $7^{\text {th }}$ day by 15.2 and $14.6 \%$, on the $14^{\text {th }}$ day the enzyme activity decreased to the level of intact animals. The Fe content was increased on the $7^{\text {th }}$ day by $23.7 \%$ compared with intact animals, on the $14^{\text {th }}$ day the Fe content decreased to the level of intact rats. Changes in biochemical markers in the group of rats that underwent subcutaneous implantation of magnets without a protective coating indicate an inflammatory reaction of the body to the introduction of implants, which was reflected in increase in glycoproteins and tended to decrease from 7 and 14 days, but the rate remained high at the end of the experiment compared with intact animals. In rats after implantation of coated magnets, the content of glycoproteins in the blood increased by $18.2 \%$ only on the $7^{\text {th }}$ day after implantation (Table 4 ).

Table 2

Dynamics of hematological parameters in rats after subcutaneous implantation of magnets with a protective $\mathrm{ZrN}$ coating (Me, 25...75\%)

\begin{tabular}{|c|c|c|c|c|}
\hline \multirow[t]{2}{*}{ Indicators } & \multirow{2}{*}{$\begin{array}{l}\text { Intact rats, } \\
\mathrm{N}=7\end{array}$} & \multicolumn{3}{|c|}{ Days after implantation } \\
\hline & & 7 & 14 & 45 \\
\hline $\begin{array}{l}\text { Erythrocytes, } \\
\mathrm{T} / \mathrm{L}\end{array}$ & $\begin{array}{l}7.00 \\
6.85 \ldots 7.20\end{array}$ & $\begin{array}{l}6.80 \\
6.70 \ldots 7.00\end{array}$ & $\begin{array}{l}7.20 \\
6.80 \ldots 7.20\end{array}$ & $\begin{array}{l}7.10 \\
6.95 \ldots 7.25\end{array}$ \\
\hline $\begin{array}{l}\text { Hemoglobin, } \\
\text { g / } 1\end{array}$ & $\begin{array}{l}144.0 \\
141.5 \ldots 146.5\end{array}$ & $\begin{array}{l}140.0 \\
139.5 \ldots 143 . .1\end{array}$ & $\begin{array}{l}141.0 \\
133.0 . .143 .0\end{array}$ & $\begin{array}{l}145.0 \\
140.5 . .146 .5\end{array}$ \\
\hline $\begin{array}{l}\text { Eoenophilia, } \\
\text { percent }\end{array}$ & $\begin{array}{l}2.0 \\
1.0 \ldots 2.0\end{array}$ & $\begin{array}{l}2.0 \\
2.0 \ldots 3.0\end{array}$ & $\begin{array}{l}1.0 \\
1.0 \ldots 2.0\end{array}$ & $\begin{array}{l}2.0 \\
1.0 \ldots 3.0\end{array}$ \\
\hline $\begin{array}{l}\text { Neutrophils, } \\
\text { percent }\end{array}$ & - & - & - & - \\
\hline Young & 0 & 0 & 0 & 0 \\
\hline Rod shapad & $\begin{array}{l}1.0 \\
1.0 \ldots 2.0\end{array}$ & $\begin{array}{l}3.0 \\
2.0 \ldots 4.0\end{array}$ & $\begin{array}{l}2.0 \\
1.0 \ldots 3.0\end{array}$ & $\begin{array}{l}2.0 \\
1.0 \ldots 2.0\end{array}$ \\
\hline Segmentedcore & $\begin{array}{l}21.0 \\
20.0 \ldots 23.0\end{array}$ & $\begin{array}{l}25.0 \\
20.0 \ldots .28 .0\end{array}$ & $\begin{array}{l}19.0 \\
17.0 . .25 .0\end{array}$ & $\begin{array}{l}21.0 \\
19.0 . .24 .0\end{array}$ \\
\hline $\begin{array}{l}\text { Lymphocytes, } \\
\text { percent }\end{array}$ & $\begin{array}{l}69.0 \\
67.0 \ldots 71.0\end{array}$ & $\begin{array}{l}67.0 \\
61.0 \ldots 68.0\end{array}$ & $\begin{array}{l}74.0 \\
67.0 . . .75 .0\end{array}$ & $\begin{array}{l}68.0 \\
66.0 . .68 .0\end{array}$ \\
\hline $\begin{array}{l}\text { Monocyt, } \\
\text { percent }\end{array}$ & $\begin{array}{l}7.0 \\
6.0 \ldots 8.0\end{array}$ & $\begin{array}{l}7.0 \\
5.0 \ldots 10.0\end{array}$ & $\begin{array}{l}6.0 \\
5.0 \ldots 7.0\end{array}$ & $\begin{array}{l}8.0 \\
7.0 \ldots 9.0\end{array}$ \\
\hline
\end{tabular}

The content of total protein, urea, total bilirubin and the activity of aminotransferases (ALT and AST) during the experiment did not differ from those in intact animals. Glucose content was increased on $7^{\text {th }}$ day after implantation by $20.3 \%$, which is apparently due to the stress response of the body at the end of the early postoperative period by analogy with rats, which were implanted without coated magnets.

At day 45, the biochemical parameters in both groups of rats did not differ from those of intact animals, which are apparently due to the formation of a connective tissue capsule around the implants, which prevented the development of local and general reactions.

Thus, it should be noted that the effect of saliva and the presence of bacteria in the oral cavity increases the corrosion of magnets. Therefore, it is extremely necessary to use coatings for magnets for further use in dentistry. After all, the coating demonstrates in dental practice much better biological properties in relation to tissues and the absence of negative morphological changes, such as necrosis and demineralization of bone tissue. It is expected that the development of the coating and its application will significantly improve the life of the implant and its quality for use in modern orthodontics. 
Table 3

Dynamics of biochemical parameters of the blood of rats after subcutaneous implantation of magnets without a protective coating (Me, $25 \ldots 75 \%)$

\begin{tabular}{|c|c|c|c|c|}
\hline \multirow{2}{*}{ Indicators } & \multirow{2}{*}{$\begin{array}{c}\text { Intact } \\
\text { rats, } N=7\end{array}$} & \multicolumn{3}{|c|}{ Days after implantation } \\
\hline & & 7 & 14 & 45 \\
\hline $\begin{array}{l}\text { Glycoproteins, } \\
\text { g/L }\end{array}$ & $\begin{array}{l}1.15 \\
1.13 \ldots 1.18\end{array}$ & $\begin{array}{l}1.46^{*} \\
1.38 \ldots 1.58\end{array}$ & $\begin{array}{l}1.25 * \diamond \\
1.23 \ldots 1.36\end{array}$ & $\begin{array}{l}1.14 \diamond \\
1.03 \ldots 1.22\end{array}$ \\
\hline $\begin{array}{l}\text { Total protein, } \\
\text { g/L }\end{array}$ & $\begin{array}{l}71.20 \\
69.80 \ldots .72 .30\end{array}$ & $\begin{array}{l}75.60 \\
66.05 \ldots 80.85\end{array}$ & $\begin{array}{l}68.70 \\
65.65 \ldots 70.40\end{array}$ & $\begin{array}{l}68.30 \\
66.95 \ldots . .72 .2\end{array}$ \\
\hline $\begin{array}{l}\text { Glucose, } \\
\mathrm{mmol} / \mathrm{L}\end{array}$ & $\begin{array}{l}5.40 \\
5.25 \ldots . .5 .60\end{array}$ & $\begin{array}{l}7.10 * \\
6.50 \ldots 7.95\end{array}$ & $\begin{array}{l}6.00 \\
5.25 \ldots 7.30\end{array}$ & $\begin{array}{l}5.10 \\
4.75 \ldots . .5 .85\end{array}$ \\
\hline $\begin{array}{c}\text { Urea, } \\
\mathrm{mmol} / \mathrm{L}\end{array}$ & $\begin{array}{l}4.10 \\
3.90 \ldots 4.15\end{array}$ & $\begin{array}{l}4.70 * \\
4.60 \ldots . .5 .00\end{array}$ & $\begin{array}{l}4.20 \\
3.60 \ldots 4.75\end{array}$ & $\begin{array}{l}4.00 \\
3.90 \ldots 4.20\end{array}$ \\
\hline $\begin{array}{c}\text { ALT activity, } \\
\text { U/L }\end{array}$ & $\begin{array}{l}66.0 \\
64.0 \ldots 69.5\end{array}$ & $\begin{array}{l}76.0 * \\
72.0 \ldots 84.0\end{array}$ & $\begin{array}{l}64.0 \diamond \\
59.5 \ldots 68.0\end{array}$ & $\begin{array}{l}67.0 \\
63.0 \ldots 72.0\end{array}$ \\
\hline $\begin{array}{c}\text { AST activity, } \\
\text { U/L }\end{array}$ & $\begin{array}{l}127.0 \\
120.5 \ldots 130.5 \\
\end{array}$ & $\begin{array}{l}121.0 \\
108.0 . .147 .5\end{array}$ & $\begin{array}{l}128.0 \\
120.5 \ldots 134.5\end{array}$ & $\begin{array}{l}129.0 \\
122.0 \ldots 134.5\end{array}$ \\
\hline $\begin{array}{l}\text { Total bilirubin, } \\
\mu \mathrm{mol} / \mathrm{L}\end{array}$ & $\begin{array}{l}4.10 \\
3.85 \ldots 4.15\end{array}$ & $\begin{array}{l}4.20 \\
3.70 . .450\end{array}$ & $\begin{array}{l}4.40 \\
3.90 \ldots 4.80\end{array}$ & $\begin{array}{l}4.20 \\
3.95 \ldots 4.40\end{array}$ \\
\hline $\begin{array}{c}\mathrm{Fe}, \\
\mu \mathrm{mol} / \mathrm{L}\end{array}$ & $\begin{array}{l}35.00 \\
32.50 \ldots 36.55\end{array}$ & $\begin{array}{l}43.30 * \\
40.35 . .47 .00\end{array}$ & $\begin{array}{l}31.40 \diamond \\
30.45 \ldots 38.60\end{array}$ & $\begin{array}{l}37.00 \\
37.70 . .38 .40\end{array}$ \\
\hline
\end{tabular}

Notes: * - probably Wilcoxon $(\mathrm{p}<0.05)$ compared to intactrats; $\diamond$ - probably Wilcoxon $(\mathrm{p}<0.05)$ compared to 7 days.

Table 4

Dynamics of biochemical parameters of rat blood after subcutaneous implantation of magnets with a protective coating (Me, 25...75\%)

\begin{tabular}{|c|c|c|c|c|}
\hline \multirow{2}{*}{ Indicators } & \multirow{2}{*}{$\begin{array}{c}\text { Intact } \\
\text { rats, } N=7\end{array}$} & \multicolumn{3}{|c|}{ Days after implantation } \\
\hline & & 7 & 14 & 45 \\
\hline $\begin{array}{l}\text { Glycoproteins, } \\
\text { g/L }\end{array}$ & $\begin{array}{l}1.15 \\
1.13 \ldots 1.18\end{array}$ & $\begin{array}{l}1.36^{*} \\
1.31 \ldots 1.42\end{array}$ & $\begin{array}{l}1.12 \diamond \\
1.02 \ldots 1.22\end{array}$ & $\begin{array}{l}1.12 \\
1.06 \ldots 1.23\end{array}$ \\
\hline $\begin{array}{l}\text { Total } \\
\text { protein, g/L }\end{array}$ & $\begin{array}{l}71.20 \\
69.80 . .72 .30\end{array}$ & $\begin{array}{l}67.20 \\
65.35 \ldots 74.35\end{array}$ & $\begin{array}{l}68.30 \\
67.05 \ldots 69.95\end{array}$ & $\begin{array}{l}71.0 \\
69.3 \ldots 71.9\end{array}$ \\
\hline $\begin{array}{l}\text { Glucose, } \\
\mathrm{mmol} / \mathrm{L}\end{array}$ & $\begin{array}{l}5.40 \\
5.25 \ldots .5 .60\end{array}$ & $\begin{array}{l}6.50 * \\
5.85 \ldots 6.75\end{array}$ & $\begin{array}{l}5.70 \diamond \\
5.15 \ldots 6.05\end{array}$ & $\begin{array}{l}5.65 \\
5.30 \ldots . .80\end{array}$ \\
\hline $\begin{array}{l}\text { Urea, } \\
\mathrm{mmol} / \mathrm{L}\end{array}$ & $\begin{array}{l}4.10 \\
3.90 \ldots .4 .15\end{array}$ & $\begin{array}{l}4.00 \\
3.75 \ldots 4.50\end{array}$ & $\begin{array}{l}3.60 \\
2.90 \ldots 4.10\end{array}$ & $\begin{array}{l}4.30 \\
4.10 \ldots 4.35\end{array}$ \\
\hline $\begin{array}{l}\text { ALT } \\
\text { activity, } \\
\text { U/L }\end{array}$ & $\begin{array}{l}66.00 \\
64.00 \ldots . .69 .50\end{array}$ & $\begin{array}{l}63.00 \\
56.00 \ldots 66.50\end{array}$ & $\begin{array}{l}62.00 \\
59.00 \ldots 69.0 \\
0\end{array}$ & $\begin{array}{l}68.5 \\
65.5 \ldots 71.5\end{array}$ \\
\hline $\begin{array}{l}\text { AST } \\
\text { activity, } \\
\text { U/L } \\
\end{array}$ & $\begin{array}{l}127.0 \\
120.5 . .130 .5\end{array}$ & $\begin{array}{l}126.0 \\
118.5 \ldots 127.5\end{array}$ & $\begin{array}{l}122.0 \\
115.5 \ldots 127.5\end{array}$ & $\begin{array}{l}129.0 \\
124.0 \ldots 132.5\end{array}$ \\
\hline $\begin{array}{l}\text { Total } \\
\text { bilirubin, } \\
\mu \mathrm{mol} / \mathrm{L}\end{array}$ & $\begin{array}{l}4.10 \\
3.85 \ldots 4.15\end{array}$ & $\begin{array}{l}4.20 \\
4.00 \ldots 4.50\end{array}$ & $\begin{array}{l}4.30 \\
3.95 \ldots . .00\end{array}$ & $\begin{array}{l}4.30 \\
3.90 \ldots 4.40\end{array}$ \\
\hline $\begin{array}{l}\mathrm{Fe}, \\
\mu \mathrm{mol} / \mathrm{L}\end{array}$ & $\begin{array}{l}35.00 \\
32.50 . . .36 .55\end{array}$ & $\begin{array}{l}29.70 \\
27.95 \ldots 34.90\end{array}$ & $\begin{array}{l}40.90 \\
30.45 \ldots . .45 .45\end{array}$ & $\begin{array}{l}37.70 \\
34.00 \ldots 38.75\end{array}$ \\
\hline
\end{tabular}

Notes: *-probably Wilcoxon $(\mathrm{p}<0.05)$ compared to intactrats; $\diamond$ - probably Wilcoxon ( $\mathrm{p}<0.05)$ compared to 7 days.

\section{CONCLUSIONS}

1. Indicators of the general clinical analysis of blood after implantation of magnets with and without protective $\mathrm{ZrN}$ coating did not change in comparison with intact animals that testify to absence of toxic influence of implants on a hemocytopoiesis.

2. The content of iron on the $7^{\text {th }}, 14^{\text {th }}$, and $45^{\text {th }}$ day of the experiment in the blood of rats, which were implanted with coated magnets, did not change, which is due, in our opinion, the lack of iron into the bloodstream by applying a protective $\mathrm{ZrN}$ coating on the surface of the magnet (implant).

3. Rats with uncoated implants have a moderate reaction of the liver parenchyma (increased ALT activity) and an increase in urea levels on the background of an increase in the concentration of iron in the blood on day 7, but on day 14 these values normalized, but the inflammatory reaction to the implant persisted leading to increased blood glycoproteins - markers of the inflammatory process; at day 45 , the biochemical parameters of the blood did not differ from those of intact animals.

4. Thus, according to the results of the study of biochemical markers of rat blood after the introduction of coated and uncoated implants, we can conclude that $\mathrm{ZrN}$ protective coating is able to prevent the release of iron and reduce the toxic response of animals to the introduction of a magnetic implant.

\section{REFERENCES}

1. L.A. Bondemark // Eur Orthod. 2000, v. 22(6), p. 683-695.

2. Klark Dzh. Ortodontic heskoye lecheniye parnymi blokami. M.: "MEDpress-inform". 2007, p. 384 (Russian).

3. N. Sharma et al. // World Journal of Dentisiry. 2015, 6(1), p. 45-48.

4. A.L. Robinson // Science. 1984, v. 223(4639), p. 920-922.

. A. Kitsugi et al. //Dent Mater J. 1992, v. 11(2), p. 119129.

6. O.V. Penkov et al. // Biomaterials. 2016, v. 102, p. 130-136.

7. L.A. Dmitriyeva. Terapevticheskaya stomatologiya' natsional'noye Rukovodstvo. M.: "Geotar-Media", 2009, 912 p. (in Russian).

8. A.V. Taran et al. // High Temperature Material Processes. 2020, v. 24(2), p. 109-120.

9. V.S. Taran et al. // Plasma Medicine. 2020, v. 10(1), p. 61-69.

10. V.S. Taran et al. // High Temperature Material Processes. 2020, v. 23(3), p. 1-12.

11. V.S. Taran et al. // Problems of Atomic Science and Technology. Series «Plasma Physics» (26). 2020, № 6(130), p. 115-118.

12. V.S. Kamyshnikov. Kliniko-biokhimicheskaya laboratornaya diagnostika. L.: "Interpresserpvis", 2003, 495 p. (in Russian).

13. A.M. Goryachkovskiy. Klinicheskaya biokhimiya $v$ laboratornoy diagnostike. Odessa: "Ekologiya", 2005, 616 p. (in Russian).

14. S. Glants. Mediko-biologicheskaya statistika. M.: "Praktika", 1998, 459 p. (in Russian).

Article received 18.12.2020 


\title{
КЛИНИЧЕСКИЙ АНАЛИЗ КРОВИ ПОСЛЕ ПОДКОЖНОЙ ИМПЛАНТАЦИИ Nd-Fе-В-МАГНИТОВ С ЗАЩИТНЫМИ ПОКРЫТИЯМИ РVD ZrN
}

\author{
В.И. Куцевляк, С.Л. Старикова, А.В. Таран, И.А. Мисирук, В.В. Стариков, А.А. Батурин, \\ Н.В. Конотопская, Л.Н. Душик, Н.В. Черкова
}

Эффективность лечения различных аномалий прикуса можно повысить с помощью ортодонтических аппаратов на основе постоянных магнитов. Существенным недостатком магнитных материалов является их низкая коррозионная стойкость, которую можно улучшить путем нанесения на магниты различных защитных покрытий PVD, приводящих к пассивации поверхности магнитного материала. Оценено влияние магнитов Nd-Fe-B с защитным покрытием $\mathrm{ZrN}$ и без него после подкожной имплантации крысам на результаты лабораторного анализа крови.

\section{КЛІНІЧНИЙ АНАЛІЗ КРОВІ ПІСЛЯ ПІДШКІРНОЇ ІМПЛАНТАЦЇ̈ Nd-Fе-В-МАГНІТІВ I3 ЗАХИСНИМИ ПОКРИТТЯМИ РVD ZrN}

\section{В.І. Куцевляк, С.Л. Старікова, А.В. Таран, І.О. Місірук, В.В. Старіков, О.А. Батурін, Н.В. Конотопська, Л.М. Душик, Н.В. Черкова}

Ефективність лікування різних аномалій прикусу можна підвищити за допомогою ортодонтичних апаратів, на основі постійних магнітів. Але суттєвим недоліком магнітних матеріалів $є$ їх низька корозійна стійкість, яку можна запобігти нанесенням на магніти різних захисних покриттів PVD, що ведуть до пасивації поверхні магнітного матеріалу. Оцінено вплив магнітів Nd-Fe-B із захисним покриттям $\mathrm{ZrN}$ та без нього після підшкірної імплантації щурам на результати лабораторних аналізів крові. 